\title{
In-Vitro Antiviral Activities of Extracts of Plants of The Brazilian Cerrado against the Avian Metapneumovirus (aMPV)
}

http://dx.doi.org/10.1590/1516-635x1703275-280

\section{-Author(s)}

Kohn LK',I

Foglio MA ${ }^{\text {III }}$

Sousa IM de OIII

Martini MC"

Padilla MA"

Lima Neto DF de

Arns CW"

Universidade de São Francisco, Rua Valdemar C. Silveira, 105, CEP 13045-510, Campinas, SP, Brazil

" Laboratory of Virology, Institute of Biology, CP 6109, University of Campinas Unicamp, 13083-970, Campinas, SP, Brazil

III Laboratory Research \& Development of Natural Products, Institute of Chemistry, CP 6154, University of Campinas - Unicamp, 13083-970, Campinas, SP, Brazil

iv Center for Chemical, Biological and Agricultural (CQBA) -University of Campinas - Unicamp, 13083-970, Campinas, SP, Brazil
Rodrigues RA ${ }^{\text {III }}$

\section{ABSTRACT}

Avian metapneumovirus (aMPV) is a negative-sense single-stranded RNA enveloped virus of the Metapneumovirus genus belonging to the Paramyxoviridae family. This virus may cause significant economic losses to the poultry industry, despite vaccination, which is the main tool for controlling and preventing aMPV. The aim of this study was to evaluate the antiviral activity of extracts of four different native plants of the Brazilian Cerrado against aMPV. The antiviral activity against aMPV was determined by titration. This technique measures the ability of plant extract dilutions ( 25 to $2.5 \mu \mathrm{g} \mathrm{mL}^{-1}$ ) to inhibit the cytopathic effect (CPE) of the virus, expressed as inhibition percentage (IP). The maximum nontoxic concentration (MNTC) of the extracts used in antiviral assay was $25 \mu \mathrm{g} \mathrm{mL}^{-1}$ for Aspidosperma tomentosum and Gaylussacia brasiliensis, and $2.5 \mu \mathrm{g} \mathrm{mL}^{-1}$ for Arrabidaea chica and Virola sebifera. Twelve different extracts derived from four plant species collected from the Brazilian Cerrado were screened for antiviral activity against aMPV. G. brasiliensis, A. chica, and V. sebifera extracts presented inhibition rates of $99 \%$ in the early viral replication stages, suggesting that these extracts act during the adsorption phase. On the other hand, A. tomentosum inhibited $99 \%$ virus replication after the virus entered the cell. The biomonitored fractioning of extracts active against aMPV may be a tool to identify the active compounds of plant extracts and to determine their precise mode of action.

\section{INTRODUCTION}

Arns, C.W.

Laboratory of Virology, Institute of Biology, CP 6109, University of Campinas Unicamp, 13083-970, Rua Monteiro Lobato, Campinas, SP, Brazil Phone/Fax: +55 1935216258 E-mail: clarns@gmail.com

\section{- Keywords}

Antiviral, Avian metapneumovirus,

Gaylussacia brasiliensis, Arrabidaea chica,

Virola sebifera, Aspidosperma tomentosum.
Submitted: February/2014

Approved: December/2014
Avian metapneumovirus (aMPV) is a negative-sense single-stranded RNA enveloped virus of the Metapneumovirus genus belonging to the Paramyxoviridae family. This family includes viruses responsible for causing respiratory diseases in turkeys and in humans. In chickens, the aMPV is involved in the etiology of a multi-factorial disease also known as the Swollen Head Syndrome (SHS). Another member of the Paramyxoviridae family that is relevant to the poultry industry is the Newcastle disease virus. Avian metapneumovirus may cause significant economic losses to the poultry industry. Although vaccination is the main tool for the control and prevention of diseases caused by aMPV, pharmaceutical intervention is required under some circumstances. Furthermore, vaccinated subjects may acquire incomplete protection and/or there may be a reversion of the vaccine virus to pathogenicity (Catelli et al., 2006).

Currently, at least 40 antiviral chemotherapeutic compounds are approved for the treatment of individuals infected with a variety of viruses (De Clercq, 2004). Most of the approved drugs and at least half of them are used for the treatment of human immunodeficiency virus (HIV) infection, as well as for the treatment of infections by herpes 
Kohn LK, Foglio MA, Rodrigues RA, Sousa IM de O, Martini MC, Padilla MA, Lima Neto DF de, Arns CW

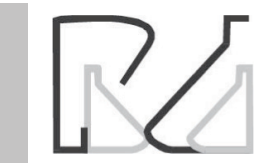

virus (e.g., herpes simplex virus, varicella zoster virus, and cytomegalovirus), hepatitis B virus, hepatitis C virus, or influenza virus. Most of the approved antiviral agents are nucleoside analogs, which inhibit viral DNA synthesis (herpes virus) or viral reverse transcription (HIV) (Mukhtar et al., 2008)

The use of different anti-microbial drugs derived from plants is currently limited to human diseases, with very few applications in veterinary medicine (Pieroni et al., 2006). However, considering the evidence accumulated to date, it is expected that their utilization will become increasingly important both in terms of limiting the environmental dissemination of pathogens and of animal health maintenance.

One of the most critical issues in the development of new antiviral drugs is the model to be used. The cell substrate requirements for virus replication limits the screening of new compounds. For this reason, few drugs have emerged as efficient antivirals (AbouKaram \& Shier, 1990 and Jassim \& Naji, 2003). New technologies aimed at increasing the throughput of the antiviral screening process and the significant advances in viral molecular biology are opening new frontiers; however, no considerable success in therapeutics has been achieved yet.

A new antiviral screening technique has been used to optimize the discovery of new substances. The technique is widely used in the discovery of drugs against cancer in order to evaluate the pharmacological properties of the compounds. Additionally, experimental models should mimic the physiological properties of the processes in the human body, thus reducing the number of false positives (Smee et al., 2002 and Cos et al., 2006).

The screening of antiviral compounds requires the development of cell-culture systems that allow optimal viral replication and the selection of the most appropriate method to evaluate the action of these compounds against viruses (Smee et al., 2002).

The cytopathic effect assay is one of the most reliable and robust assays for the screening of large compound libraries, and it has been successfully adapted into a high throughput format for the identification of novel antiviral agents against a number of viruses. The influenza virus (Noah et al., 2007 and Severson et al., 2008), the severe acute respiratory syndrome coronavirus (SARS-CoV) (Severson et al., 2007), the arenavirus (Bolken et al., 2006), and the bluetongue virus (Li et al., 2009) were identified using this technique.

\section{In-Vitro Antiviral Activities of Extracts of Plants of The Brazilian Cerrado against the Avian Metapneumovirus (aMPV)}

This study aimed at evaluating the antiviral activity of four different Brazilian Cerrado plants against aMPV. In addition, aMPV could be a surrogate to evaluate other members of the Paramyxoviridae family with similar replication characteristics.

\section{MATERIALS AND METHODS}

\section{Extraction of plant material}

Plants were obtained from the Cerrado biome (the second largest biome in South America) and deposited at the University of Campinas, Campinas, SP, Brazil (Table 1).

Table 1 - Cerrado plant and description of each extracts used for aMPV screening.

\begin{tabular}{|c|c|c|}
\hline Itens & $\begin{array}{c}\text { Plants/ Voucher } \\
\text { (registration } \\
\text { number) }\end{array}$ & Description of Extracts \\
\hline 01 & \multirow{3}{*}{$\begin{array}{l}\text { Aspidosperma } \\
\text { tomentosum } \\
\text { Mart. } \\
\text { UEC-IB-267* }\end{array}$} & $\begin{array}{l}\text { Extraction at room temperature with ethyl } \\
\text { acetate }\end{array}$ \\
\hline 02 & & $\begin{array}{l}\text { Extraction at room temperature with } \\
\text { dichloromethane }\end{array}$ \\
\hline 03 & & $\begin{array}{l}\text { Extraction at room temperature with } \\
\text { acetone }\end{array}$ \\
\hline 04 & \multirow{5}{*}{$\begin{array}{l}\text { Gaylussacia } \\
\text { brasiliensis } \\
\text { (Spreng.) Meisn. } \\
\text { UEC-IB-266* }\end{array}$} & $\begin{array}{l}\text { Extraction at room temperature with } \\
\text { dichloromethane }\end{array}$ \\
\hline 05 & & $\begin{array}{l}\text { Extraction at room temperature with } \\
\text { acetone }\end{array}$ \\
\hline 06 & & $\begin{array}{l}\text { Extraction at room temperature with ethyl } \\
\text { acetate }\end{array}$ \\
\hline 07 & & $\begin{array}{l}\text { Extraction at room temperature with } \\
\text { ethanol } 70 \%\end{array}$ \\
\hline 08 & & $\begin{array}{l}\text { Extraction at room temperature with } \\
\text { ethanol } 60 \%\end{array}$ \\
\hline 9 & Virola sebifera & Soxhlet extraction with dichloromethane \\
\hline 10 & UEC-IB-258* & Soxhlet extraction with ethanol \\
\hline 11 & Arrabidaea chica & $\begin{array}{l}\text { Ethanol/ } 0.3 \% \text { citric acid extraction with no } \\
\text { enzymatic treatment }\end{array}$ \\
\hline 12 & CPQBA-1348** & $\begin{array}{l}\text { Ethanol/ } 0.3 \% \text { citric acid extraction with } \\
\text { enzymatic treatment }\end{array}$ \\
\hline
\end{tabular}

* UEC-IB-267; UEC-IB-266 and UEC-IB-258: Deposited at the Institute of Biology, State University of Campinas - Campinas/SP, Brazil.

** CPQBA-1348: Deposited at the Center for Chemical, Biological and Agricultural (CQBA) - State University of Campinas, Campinas/SP, Brazil

Extracts from the leaves of Aspidosperma tomentosum Mart., known as "peroba-do-cerrado" (1); Virola sebifera L., known as "ucuúba-do-cerrado or mucuíba" (2); and Gaylussacia brasiliensis Meisn, known as "camarinha" (3) were obtained by using dichloromethane, and the resulting compound was further extracted with $70 \%$ ethanol in combination with maceration at room temperature. The plant Arrabidaea chica Verlot. known as "carajuru and guajuru-piranga" (4), was submitted to enzymatic treatment with xylase, followed by extraction with methanol supplemented 
Kohn LK, Foglio MA, Rodrigues RA, Sousa IM de O, Martini MC, Padilla MA, Lima Neto DF de, Arns CW

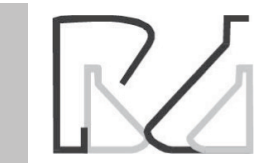

with $3.0 \mathrm{~g}$ of citric acid, resulting in an enzyme crude extract (CE). A crude extract of $A$. chica (4) with no enzymatic treatment was also obtained (SE).

\section{Virus and cell line}

The CER cells (chicken embryo related cell) were propagated as monolayer cultures using minimal essential medium (MEM) with Earle's salts and supplemented with 10\% fetal bovine serum (FBS). Cells were serially diluted from $1: 2$ to $1: 10$, according to conventional procedures using $0.05 \%$ trypsin and $0.02 \%$ ethylenediaminetetraacetic acid (EDTA).

The aMPV strain SHS/669/03 was isolated by D'Arce et al. in 2005 and belongs to aMPV subtype A. When the virus was incubated with the cells, the MEM medium was not supplemented with FBS.

\section{Cell cytotoxic effect}

Maximum nontoxic concentration (MNTC) was determined microscopically by the observation of morphological changes in the cells at 24, 48 and 72 hours of incubation. Cell suspensions were seeded at $100 \mu \mathrm{L} /$ well in a 96-well culture plate at a density of $1 \times 10^{5}$ cells $/ \mathrm{mL}$. The plates containing cells were pre-incubated for $24 \mathrm{~h}$ at $37^{\circ} \mathrm{C}$ to allow stabilizations prior to the addition of samples $(100 \mu \mathrm{L})$ at four concentrations $\left(0.25,2.5,25\right.$, and $\left.250 \mu \mathrm{g} \cdot \mathrm{mL}^{-1}\right)$ (Kohn et al., 2007).

Cytotoxicity after $72 \mathrm{~h}$ was measured using the sulforhodamine B (SRB) assay, performed as described by Kohn et al. (2007). Briefly, the cells were fixed using $50 \%$ Trichloroacetic Acid (TCA) at $4^{\circ} \mathrm{C}(50 \mu \mathrm{L}$ per well, final concentration $10 \%$ ) for $1 \mathrm{~h}$. The supernatant was discarded and the plates were washed five times with filtered water. The cells were stained for $30 \mathrm{~min}$ with $0.4 \%$ SRB in $1 \%$ acetic acid $(50 \mu \mathrm{L}$ per well) and subsequently washed four times with $1 \%$ acetic acid to remove any unbound dye. The plates were airdried, and protein-bound dye was solubilized with 150 $\mu \mathrm{L}(100 \mathrm{mM})$ of Trizma buffer. The resulting optical density (OD) was read in a multi-well plate under a spectrophotometer at $540 \mathrm{~nm}$.

\section{Virus titration}

The cells were seeded in 96-well culture plates at a density of $1 \times 10^{5}$ cells $/ \mathrm{mL}$ and then incubated at 37 ${ }^{\circ} \mathrm{C}$ in a humidified atmosphere containing $\mathrm{CO}_{2}$ for 24 h. Serial dilutions of virus stocks were prepared and cells were infected accordingly. After an additional incubation period (1-2 days), the cytopathic effect was recorded. The $50 \%$ tissue-culture infective dose
In-Vitro Antiviral Activities of Extracts of Plants of The Brazilian Cerrado against the Avian Metapneumovirus (aMPV)

$\left(\mathrm{TCID}_{50}\right)$ per $\mathrm{mL}$ was calculated as previously described by Reed \& Münch (1938).

\section{Antiviral activity}

The determination of the antiviral activity of evaluated plant extracts was based on cytopathic effect inhibition. All experiments were performed in triplicate. For the evaluation of inhibition, cells were seeded in 96-well culture plates. After $24 \mathrm{~h}$ of incubation, the medium was replaced with $100 \mu \mathrm{L}$ Dulbecco's Modified Eagle's Medium (DMEM), containing the plant extracts at MNTC, and $50 \mu \mathrm{L}$ of logarithmic dilutions of the virus were added in quadruplicate; the plates were incubated for 3 days. Controls consisted of untreated infected (virus titer), treated non-infected (extract control), and untreated non-infected (cell control) cells. Viral titers was calculated as previously described by Reed and Münch (1938), and determined as $50 \%$ of the infective dose in tissue culture $\left(\mathrm{TCID}_{50} / \mathrm{mL}\right)$. Antiviral activity of each extract was determined as the logarithm reduction factor $\left(\log _{10}\right)$ of the viral titer compared with untreated infected controls. Values were expressed as titer $\left(\mathrm{TCID}_{50} / \mathrm{mL}\right)$ and inhibition percentage (IP), as described in Koseki et al. (1990). The inhibition percentage was calculated according to the formula: $(\mathrm{IP})=(1-\mathrm{T} / \mathrm{C})$ $x 100$, where $T$ is the antilog of the extract-treated viral titers and $C$ is the antilog of the control (without extract) viral titers. IP was considered positive if greater than or equal to $98 \%$.

The antiviral activity was initially evaluated with a single dose at MNTC against different viral concentrations. The extract was considered positive if there was a 1.5 log decrease in the viral titer. In order to confirm antiviral activity, a concentration response curve with different extract concentrations in the presence of $100 \mathrm{TCID}_{50} / \mathrm{mL}$ was calculated using the MTT'1 assay to establish the half maximal effective concentration (EC50). Briefly, an MTT solution at 5 $\mathrm{mg} \cdot \mathrm{mL}^{-1}$ in PBS was added to the 96-well culture plates at $20 \mu \mathrm{L} /$ well at each time point. Following $4 \mathrm{~h}$ of incubation, $100 \mu \mathrm{L}$ of DMSO was added to each well and mixed thoroughly to dissolve the dark-blue formazan crystals from surviving cells. The resulting optical density (OD) was read in a multiwell plate in a spectrophotometer at $540 \mathrm{~nm}$ (Mosmann, 1983 and Scudiero et al., 1988).

MTT is a cell viability assay. According to Mossmann (1983), the MTT (3-(4,5-dimethylthiazol-2-yl)-2,5-diphenyltetrazolium bromide) tetrazolium reduction assay was the first homogeneous cell viability assay developed for a 96-well format that was suitable for high throughput screening (HTS). 
Kohn LK, Foglio MA, Rodrigues RA, Sousa IM de O, Martini MC, Padilla MA, Lima Neto DF de, Arns CW

\section{Statistical analysis}

The $50 \%$ cytotoxic $\left(\mathrm{CC}_{50}\right)$ and $50 \%$ inhibition $\left(\mathrm{IC}_{50}\right)$ concentrations were calculated from concentrationeffect curves. The results were obtained from triplicate assays with at least five extract concentrations. The percentage of cytotoxicity was calculated as $[(A-B) / A]$ $x 100$, where $A$ and $B$ are the OD $540 \mathrm{~nm}$ of untreated and of treated cells, respectively. The percentages of protection were calculated as [ $A$ - B $) \times 100 /(C$ $B)$ ], where $A, B$ and $C$ indicate the absorbance of the extracts or fractions, virus and cell controls, respectively. Each obtained $\mathrm{EC}_{50}$ value was defined as the effective concentration that reduced the absorbance of infected cells to $50 \%$ when compared with cell and virus controls. The $\mathrm{CC}_{50}$ and $\mathrm{IC}_{50}$ of each compound were obtained from dose-effect curves (not shown). The $C C_{50}$ and $I C_{50}$ are the average of three assays with five concentrations within the inhibitory range of the compounds. The selective index was defined as $C C_{50} / I_{50}$

\section{Potential stage of the viral infection cycle}

Cells and viruses were incubated with the active plant extracts at different stages during the viral infection cycle in order to assess different modes of antiviral action (virus inactivation before infection or during the virus adsorption and replication phases). Cells were pretreated with the extracts prior to viral infection (virus inactivation); viruses were incubated with the extracts before infecting the cells (adsorption phase); the cells were infected with the virus and incubated with the plant extracts (replication phase). Each extract was used at its maximum noncytotoxic concentration.

\section{Statistical analysis}

The selectivity index ( $\mathrm{SI}$ ) was determined as the EC50 to IC50 ratio. All experiments were performed in triplicate, and three independent experiments were conducted. Data are presented as mean \pm SD. The Student's t-test was used to evaluate the difference between the test and control samples. Differences were considered statistically significant when $p$-value was $<0.05$.

\section{RESULTS AND DISCUSSION}

Medicinal plants have been traditionally used for the treatment of different health conditions, including infectious diseases (Severson etal., 2008; Li etal., 2009). According to Cragg's 2009 report, approximately $60 \%$ of the anti-tumor and anti-infective agents that are
In-Vitro Antiviral Activities of Extracts of Plants of The Brazilian Cerrado against the Avian Metapneumovirus (aMPV)

commercially available or in late stages of clinical trials today are of natural product origin. Therefore, there is no doubt that traditional medicinal plants may serve as potential sources for the development of new antiviral agents in the future.

Developing new antiviral drugs is a difficult task due to the poor selective toxicity and fast selection of resistant viral variants that naturally arise given a selective pressure. The frequency of viral resistance to antiviral drugs is increasing and consequently, viral diseases remain difficult to treat.

The screening of plants as possible sources of antiviral agents has led to the discovery of potent inhibitors of in-vitro viral replication, increasing the probability of identifying new bioactive plant compounds (Severson et al., 2008; Li et al., 2009).

In-vitro assays usually rely on the virus ability to infect and replicate in specific cell lines in cell culture systems. Cell culture systems provide a rapid and reliable method to grow viruses at higher titers, to apply reverse genetics, and to test antiviral compounds.

A total of 12 extracts derived from four plant species collected from the Brazilian Cerrado were screened for antiviral activity against aMPV. Table 1 shows the plant names and extraction procedures. The results suggests that there is an increasing activity of the extract $A$. tomentosum acetone and $\mathrm{G}$. brasiliensis dichloromethane with SI higher than 1.5. However, the most active extracts against AMPV were from A. chica and $V$. sebifera with an inhibition percentage of $99 \%$, both extracted with acetone. The four extracts were tested to determine in which phase of the virus replication cycle they were most active.

The first stage of the antiviral assay is necessary to determine the maximum concentration (MNTC) of the extract that is not toxic to the cells. After the MNTC of the extracts was determined, $25 \mu \mathrm{g} \mathrm{mL}-1$ of Aspidosperma tomentosum and Gaylussacia brasiliensis, and $2.5 \mu \mathrm{g} \mathrm{mL} \mathrm{L}^{-1}$ of Arrabidaea chica and Virola sebifera were applied. The concentration range used to assess the activity of the extracts did not induce significant toxicity to the host cells and the $50 \%$ cytotoxic concentration (CC50) determined for each extract were well tolerated by the CER cells. The CC50 ranged from 25 to $0.25 \mu \mathrm{g} \mathrm{mL}^{-1}$ and none of the extracts tested induced any visible changes in cell morphology and cell density.

In order to identify the step of the viral cycle where replication was prevented, cells were infected with viruses after pre-incubating the cells with each evaluated extract. The viruses were pretreated with the 
Kohn LK, Foglio MA, Rodrigues RA, Sousa IM de O, Martini MC, Padilla MA, Lima Neto DF de, Arns CW

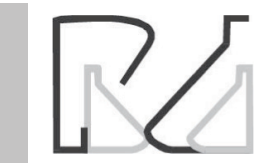

extracts prior to infection and were added during or after the adsorption phase or during the intracellular replication period. Three different treatments were applied. The cells were infected with the virus, followed by addition of the extracts after $1 \mathrm{~h}$ in order to evaluate the viral replication phase, viruses were pretreated with the extract before infecting the cells (virus inactivation), while the extract were added to the cells before viral infection to evaluate any effects during viral adsorption. In all experiments, the extracts were used at their MNTC, and the results are shown in Figures 1 and 2.

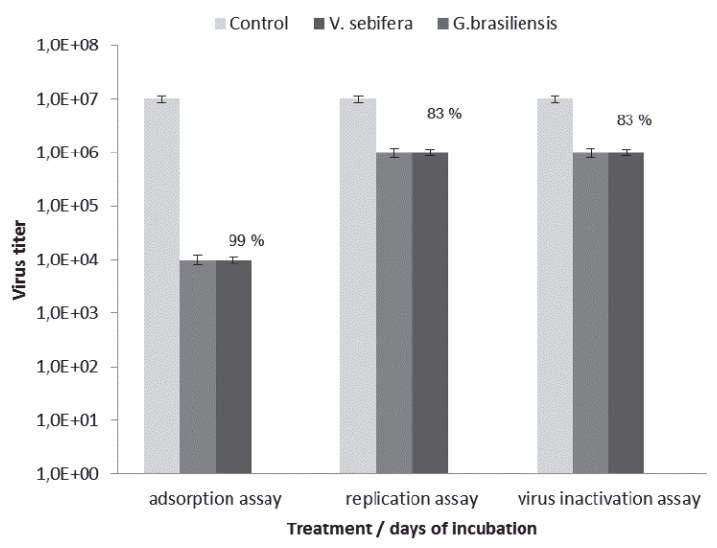

Figure 1 - Antiviral activity, as determined by inhibition percentage (IP), using virus adsorption, replication and inactivation assays of Virola sebifera and Gaylussacia brasiliensis extracts. Virus titer (TCID50) was determined three days after infection and compared with untreated control cells. Virus and CER cells were pretreated with each extract at MNTC. Experiments were independently repeated and data presented here represent the average of three experiments.

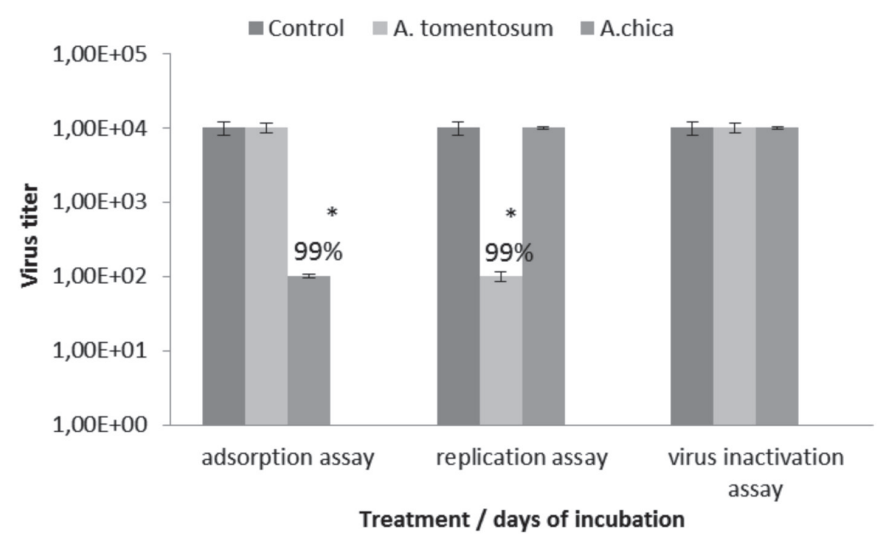

Figure 2 - Antiviral activity, as determined by inhibition percentage (IP), using virus adsorption, replication and inactivation assays of Aspidosperma tomentosum and Arrabidaea chica. Virus titer (TCID50) was determined three days after infection and compared with untreated control cells. Virus and CER cells were pretreated with each extract at MNTC. Experiments were independently repeated and data presented here represent the average of three experiments.

The analyses of the results (Figures 1 and 2) suggest that the $G$. brasiliensis, A. chica, and $V$. sebifera extracts inhibit $99 \%$ of the virus during the early replication stage and that these extracts act during the viral adsorption phase. The fact that the extracts maintained their activity under these conditions suggests that they
In-Vitro Antiviral Activities of Extracts of Plants of The Brazilian Cerrado against the Avian Metapneumovirus (aMPV)

establish stable bonds with virus receptors on the cell surface. However, this may also be due to other inhibitory mechanisms acting during the adsorption or penetration of the virus into the cell. Further studies should be conducted to determine the precise mode of action of these extracts. The $50 \%$ cytotoxic $\left(\mathrm{CC}_{50}\right)$ and $50 \%$ inhibition $\left(\mathrm{IC}_{50}\right)$ concentrations, as well as the selective index (SI) of the extracts active against aMPV were calculated and are listed in Table 2.

Table $\mathbf{2}$ - Inhibition percentage (IP), 50\% cytotoxic (CC50) and $50 \%$ inhibition (IC50) concentrations, and selective index (SI) of the four extracts against aMPV in CER cell line.

\begin{tabular}{|c|c|c|c|c|}
\hline Crude Extract & IP & CC50 & IC50 & $\mathrm{SI}$ \\
\hline & $(\%)$ & & $\mu \mathrm{g} \cdot \mathrm{mL}-1 \pm \mathrm{SD}$ & \\
\hline $\begin{array}{l}\text { Aspidosperma } \\
\text { tomentosum }\end{array}$ & 97 & $64.9 \pm 0.05$ & $45.86 \pm 0.02$ & 1.5 \\
\hline Gaylussacia brasiliensis & 99 & $41.23 \pm 0.03$ & $22.33 \pm 0.12$ & 1.8 \\
\hline Virola sebifera & 99 & $2.7 \pm 0.08$ & $202 \pm 0.05$ & 0.1 \\
\hline Arrabidaea chica & 99 & $117.1 \pm 0.017$ & $7 \quad 412.7 \pm 0.018$ & 0.3 \\
\hline
\end{tabular}

\section{CONCLUSION}

Despite continuous advances made in antiviral therapy, viral diseases are still the leading cause of death globally. Being obligate intracellular parasites, the replication of viruses is dependent on the metabolic pathways of the host cell. Since viruses and hosts are intimately connected, the design of effective antiviral agents that attack viral enzymes or virus replication, without affecting the host cell, has proven to be difficult.

The results of the present investigation provide further evidence of the potential use of medicinal plants, which possibly represent a reservoir of pharmacologically active substances. The study showed that $A$. tomentosum, $V$. sebifera, $G$. brasiliensis, and A. chica crude extracts are capable of inhibiting $99 \%$ of aMPV in vitro. However, further studies on plant fractions, aiming at isolating and identifying their active compounds and at determining their precise mode of action are required.

\section{ACKNOWLEDGMENTS}

This research was supported by Fundação de Amparo a Pesquisa do Estado de São Paulo (FAPESP) grant 2008/00700-4 to CWA. LKK thanks FAPESP for a post-doctoral scholarship (2008/00331-9), and Conselho Nacional de Desenvolvimento Científico e Tecnológico (CNPq) for the post-doctoral scholarship (503259/2011-1).

C.W. Arns and M.A. Foglio are CNPq research fellows. 


\section{REFERENCES}

Abou-Karan M, Shier WT. A simplified plaque reduction assay for antiviral agents from plants. Demonstration of frequent occurrence of antiviral activity in higher plants. Journal Natural Products 1990;53:340-44.

Bolken TC, Laquerre S, Zhang Y, Bailey TR, Pevear DC, Kickner SS, et al. Identification and characterization of potent small molecule inhibitor of hemorrhagic fever New World arenaviruses. Antiviral Research 2006;69, 86-97.

Newman JD, Cragg GM. Natural product scaffolds as leads to drugs. Future Medicinal Chemistry 2009;1:1415-27.

Catelli M, Cecchinato CE, Savage RC, Jones CJ. Demonstration of loss of attenuation and extended field persistence of a live avian metapneumovirus vaccine. Vaccine 2006: 24:6476-6482.

Cos P, Vlietink AJ, Berghe DV, Maes L. Antiinfective potential of natural products: how to develop a stronger in vitro 'proof-of-concept'. Journal of Ethnopharmacology 2006; 106:290-302.

De Clerq E. Antiviral drugs in current clinical use. Journal of Clinical Virology 2004;30:115-133.

Jassim SA, Naji MA. Novel antiviral agents: a medicinal plant perspective. Journal of Applied Microbiology 2003;95:412-27.

D'Arce RC, Coswig LT, Almeida RS, Trevisol IM, Monteiro MCB, Rossini LI, et al. Subtyping of new Brazilian avian metapneumovirus isolates from chikens and turkeys by reverse transcriptase-nested-polymerase chain reaction. Avian Pathology 2005;34(2):133-136.

Kohn LK, Pavam CH, Veronese D, Coelho F, De Carvalho JE, AlmeidaWP. Antiproliferative effect of Baylis-Hillman adducts and a new phthalide derivative on human tumor cell lines. European Journal of Medical Chemistry 2006;41:738-44.

Li Q, Maddox C, Rasmussen L, Hobrath JV, White LE. Assay development and high-throughput antiviral drug screening against Bluetongue virus. Antiviral Research 2009; 83:267-273.

Mosmann T. Rapid colorimetric assay for cellular growth and survival: application to proliferation and cytotoxicity assays. Journal Immunological Methods 1983;65:55-63.
Mukhtar M, Arshad M, Ahmad M, Pomerantz RJ, Wigdahl B, Parveen Z. Antiviral potentials of medicinal plants. Virus Research 2008;131:11120.

Noah JW, Severson W, Noah DL, Rasmussen L, White EL, Jonsson CB. A cellbased luminescence assay is effective for high-throughput screening of potential influenza antivirals. Antiviral Research 2007;73:50-59.

Pieroni ME, Giusti C, de Pasquale C, Lenzarini E, Censorii MR, GonzálesTejero C, Sánchez-Rojas CP, Ramiro-Gutiérrez JM, Skoula M, Johnson C, Sarpaki A, Della A, Paraskeva-Hadijchambi D, Hadjichambis A, Hmamouchi M, El-Jorhi S, El-Demerdash M, El-Zayat M, Al-Shahaby O, Houmani Z, Scherazed M. Circum-mediterranean cultural heritage and medicinal plant uses in traditional animal healthcare: a field survey in eight selected areas within the RUBIA project. Journal of Ethnobiological and Ethnomedical 2006; 2:16-28.

Reed $\mathrm{LJ}$, Muench $\mathrm{H}$. A simple method of estimating fifty percent endpoints. American. Journal of Public Hygiene 1938;27:493-497.

Scudiero DA, Shoemaker RH, Paull KD. Evaluation of a soluble tetrazolium/ formazan assay for cell growth and drug sensitivity in culture using human and other tumor cell lines. Cancer Research 1988:48:48274833.

Severson WE, McDowell M, Ananthan S, Chung DH, Rasmussen L, Sosa MI, White EL, Noah J, Jonsson CB. High-throughput screening of a 100,000 -compound library for inhibitors of influenza A virus (H3N2). Journal of Biomolecular Screening 2008; 13:879-887.

Severson WE, Shindo N, Sosa M, Fletcher T, White EL, Ananthan S, Jonsson CB. Development and validation of a high-throughput screen for inhibitors of SARS COV and its application in screening of a 100,000-compound library. Journal of Biomolecular Screening 2007:12:33-40

Smee DF, Morrison AC, Barnard DL, Sidwell RW. Comparison of colorimetric, fluorometric, and visual methods for determining anti-influenza ( H1N1 and H3N2) virus activities and toxicities of compounds. Journal. Virological Methods 2002;106:71-9. 